Minireview

\title{
Chlorophyll isolation, structure and function: major landmarks of the early history of research in the Russian Empire and the Soviet Union*
}

\author{
Alexander A. Krasnovsky Jr \\ Biology Department, Moscow State University and A.N. Bach Institute of Biochemistry, Russian Academy of \\ Science, Moscow 119071, Russia (e-mail: phoal@mail.ru; fax: +7-095-9542732)
}

Received 30 August 2002; accepted in revised form 24 October 2002

Key words: V.M. Arzikhovskii, I.P. Borodin, B.Ya. Dain, V.B. Evstigneev, A.S. Famintzin, T.N. Godnev, D.I. Iwanowsky, A.A. Krasnovsky, V.N. Lubimenko, L.P. Marchlewski, N.A. Monteverde, G.A. Nadson, M.V. Nencki, V.I. Palladin, E.I. Rabinowitch, S.A. Rachinskii, R.V. Teis, A.N. Terenin, C.A. Timiriazeff (also known as Timiriazev), M.S. Tswett,A.P. Vinogradov

\begin{abstract}
This paper covers major events of the early history of chlorophyll research in the Russian Empire and the Soviet Union from 1771 until 1952, when the modern period of studies on photosynthesis began in full swing. Short biographical sketches of key scientists, reviews of their major research contributions and some selected photographs are included.
\end{abstract}

\section{The earliest history (1771-1922)}

The very beginning

Basic discoveries of Joseph Priestley (1771) in the UK were highly appreciated in the Russian Empire. In 1781, Priestley was elected an honorary member of the St. Petersburg Academy of Science. Since 1800, when Jean Senebier published his fivevolume monograph 'Le Physiologie vegètale,' photosynthesis research was considered a part of plant physiology. The historical literature shows that occasional papers in this field appeared in Russia during the first part of the 19th century. However, rapid progress began in the 1860 s under the rule of the Emperor Alexander II, during the general renaissance of Russian science. An official birthdate of Russian plant physiology was 1863 , when the university constitution was approved, which suggested the organization of special plant physiology departments (chairs). The first 'ordinary professor' of plant

\footnotetext{
* This paper is dedicated to the memory of my father, academician Alexander Abramovitch Krasnovsky on his 90th birthday and the 10th anniversary of this death, both of which will fall in 2003 .
}

physiology was Sergei Alexandrovitch Rachinskii (1833-1902), who held this position at the Moscow University during 1863-1867. Rachinskii was widely recognized for his teaching activities and the first Russian translation of the Charles Darwin's book 'The Origin of Species.' Andrei Sergeevitch Famintzin (1835-1918) was the first Russian plant physiologist who devoted all his life to this branch of science (Figure 1). He graduated from the St. Petersburg University and then passed a three-year training course in Italy and Germany. In 1861, he organized the first lecture course on plant physiology at the St. Petersburg University and a research laboratory at home. His 1866 doctoral dissertation 'Action of light on algae and certain related organisms' (at St. Petersburg) and subsequent papers dealt with the dependence of photosynthesis on the intensity and quality of light, greening of etiolated seedlings, lichens and symbiosis of algae and fungi. In 1867, he organized a chair of plant physiology and became the first plant physiology professor of the St. Petersburg University. Famintzin did much for the popularization of plant physiology in Russian society. He published his lecture course (1875), the first Russian manual on 

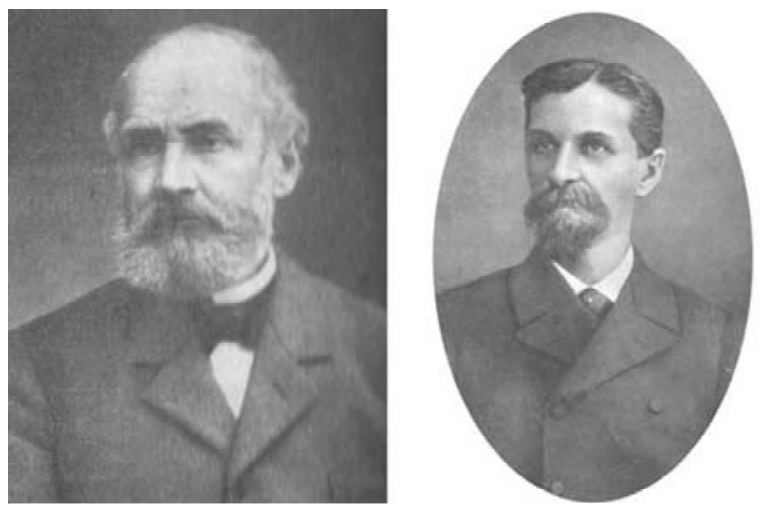

Figure 1 (left). Andrei Sergeevitch Famintzin (1835-1918), one of the founders of Russian plant physiology. From Kursanov (1967). Figure 2 (right). Climent Arkad'evitch Timiryazev (1843-1920). From Timiriazeff (1948, published posthumously).

Plant Physiology (1887), a monograph 'Metabolism and energy transformation in plants' (1883), and delivered many public lectures. In 1890, he organized a 'Laboratory of Plant Anatomy and Physiology' at the Imperial Academy of Science, which was later transformed into the Institute of Plant Physiology, and began to publish the first regular journal devoted to problems of plant physiology: 'Trudy Botanicheskoy Laboratorii Imperatorskoi Akademii Nauk' (Works of the Botanical Laboratory of the Imperial Academy of Science), which was later transformed into the Russian Journal of Plant Physiology (Famintzin 1866; Brokhauz and Effron 1899; Kursanov 1967; Kuznetzov and Stroganov 1995 and references therein).

\section{Chlorophyll as a photosensitizer of photosynthesis}

Climent Arkad'evitch Timiriazeff (1843-1920) (Figure 2) graduated from St. Petersburg University in 1866 where he listened to Famintzin's course on plant physiology. In 1867, D.I. Mendeleev invited him to work on his project; for one year he studied dependence of plant productivity on mineral fertilizers and published a paper on this subject. In 1868, he obtained a stipend from St. Petersburg University for a trip to Europe. He went to Heidelberg where he worked with G. R. Kirchhoff, R. Bunsen and G.L.F. Helmholtz, and then to Paris to work with J.B. Boussingault and M. Berthelot. In 1870, he returned to Russia. In 1871, he defended his 'magister' dissertation 'Spectral Analysis of Chlorophyll,' and in 1875, his doctoral dissertation 'On the Utilization of Light by Plants.' From 1870 he worked at the Peter's Academy of Agriculture and Forestry in Moscow and later also at Moscow University. Chlorophyll (Chl) and its function in photosynthesis were his major interests in science. It is noteworthy, that the term "chlorophyll' was proposed in 1817 by the French chemists P. Pellitier and J. Caventou to denote an alcoholic pigment extract from leaves treated with boiled water when nothing was known about 'chlorophyll' composition and biological roles. In 1838, a Swedish chemist, Jöns Jakob Berzelius (an honorary member of the St. Petersburg Academy of Science since 1820), proposed that 'chlorophyll' was a mixture of at least two compounds. G.G. Stokes (1862-1864), E. Fremy (1860-1866) and Timiriazeff (1869-1871) rigorously supported this idea. According to Timiriazeff, 'chlorophyll' was a mixture of a yellow matter 'xanthophyll' (Berzelius's term) and a blue-green matter 'chlorophyllin' (Timiriazeff's term). Working in Heidelberg, Timiriazeff observed that 'chlorophyllin' solutions and green leaves have distinct red absorption bands. Similar observations were made in parallel experiments by T. Lunewsky in Warsaw in 1870 and later by A.N. Wolkoff (1876, Novorosiisk, Heidelberg), V. Dement'ev (1876, Moscow), G. Kraus (1872, Germany) and other researchers. Timiriazeff proposed that 'chlorophyllin' is a photosensitizer of photosynthesis. During 1869-1885, he repeatedly demonstrated, using different methods, that the main maximum of the action spectrum of $\mathrm{CO}_{2}$ assimilation and oxygen production by green plants is in the red, close to the red absorption maximum of 'chlorophyllin.' These data were of great importance because many researchers (W. Draper, J. Sachs, W. Pfeffer et al., during the period of 1844-1871) thought that maximum efficiency corresponded to blue-green or green-yellow light and coincided with the maximum efficiency of vision. Timiriazeff's data correlated with the preliminary observations of Wolkoff (1866), who claimed that the maximum of the photosynthesis action spectrum is shifted to the red, as compared to that for the phototransformation of silver salts. Later, the existence of the red maximum in the action spectrum of photosynthesis was also observed by a German scientist N. Müller (during 1872-1875) and finally proved by two other German scientists T.W. Engelmann and J. Reinke (during 1882-1884) (Timiriazeff 1869, 1871, 1904, 1923; Lubimenko 1910; Lubimenko and Brilliant 1924; Kursanov 1967 and references therein).

To explain the photosensitization mechanism of 'chlorophyllin,' Timiriazeff proposed that it combines the properties of an optical and chemical photosensitizer. He thought that the structures and mechanisms 
of action of chlorophyllin and hemoglobin might be similar, and therefore, chemical photosensitization might be a result of 'chlorophyllin' photoreduction or photooxidation. Preliminary evidence in favor of $\mathrm{Chl}$ reduction by zinc was presented in the early experiments of Berzelius (1838). Timiriazeff described a reversible reaction ('Timiriazeff reaction'), which consisted of the discoloration of $\mathrm{Chl}$ after the addition of zinc powder and acetic acid to air-free solutions of Chl in pyridine, followed by restoration of the initial color after oxygen purging (Timiriazeff 1904, 1923 and references therein). Many researchers later studied this reaction. It was shown that its mechanism is strongly dependent on the experimental conditions. In certain cases the reaction was irreversible and led to Chl destruction, while in some cases it was fully reversible and corresponded to Timiriazeff's scheme (Godnev and Kalishevitch 1945; Kosobutskaya and Krasnovskii 1950; Rabinowitch 1951; Evstigneev and Gavrilova 1956; Seely 1977 and references therein). In 1896, Timiriazeff stopped his experimental work and concentrated his efforts on the popularization of photosynthesis research. He stressed the cosmic role of plants and $\mathrm{Chl}$, which are bridged between the living nature of our planet and the Sun. His major concepts were summarized in the Croonian lecture delivered in 1903 at the London Royal Society (Timiriazeff 1904) and in the book 'Sun, life and chlorophyll' finished just before his death, which comprised his major publications and lectures (Timiriazeff 1923, published posthumously).

\section{Chlorophyll isolation and structure}

In view of the fact that extracted 'chlorophyll' was a mixture of many compounds, it was very important to find a procedure for extraction of the green pigment alone. In 1881, a St. Petersburg botanist and plant physiologist Famintzin's pupil Ivan Parfen'ievitch Borodin (1847-1930) (Figure 3), found that if leaves were fixed by alcohol and dried, one could see through the microscope triangular or hexangular dark-green crystals readily dissolved in ether and insoluble in benzene and petroleum ether. Crystals were found in 190 plant species among 776 investigated. Borodin proposed that the crystals belonged to modified chlorophyll (Borodin 1881, 1882). Borodin was widely recognized for his outstanding contributions to the development of Botany in Russia. In particular, he founded the Russian Botanical Journal. Borodin's crystals attracted the attention of many re- searchers. During 1890-1893, Nikolai Avgustinovitch Monteverde (1856-1929) (Figure 4) continued this work. Monteverde was Famintzin and Borodin's pupil and the principal botanist of the Imperial St. Petersburg Botanical Garden. He showed that the red absorption spectrum of the crystal-forming pigment was similar to that of chlorophyll (Monteverde 1893).

Mikhail Semenovitch Tswett (1872-1919) (Figure 5) finally solved the problem of Chl isolation. Tswett was born in Italy, graduated from Geneva University in 1896 and then moved to St. Petersburg where he worked in contact with Famintzin's group. In 1900, he defended his 'magister' dissertation 'Physico-Chemical Composition of the Chlorophyll Grain' at the Kazan University. He formulated in it the principles of the chromatography method ('chromatography' is Tswett's term), and showed the existence of two Chls in the chlorophyll grain. In 1901, Tswett moved to Warsaw. In 1910, he published his major work 'Chromophylls in Plant and Animal World,' which was also his doctoral dissertation, defended at the Warsaw University. This work is usually considered to be a formal starting point of the chromatography method. Using this method, he finally proved that 'chlorophyll' is a mixture of two green pigments, 'chlorophyllins alfa and beta' and several yellow pigments (Figure 6). He also found that Borodin's pigment is chemically different from natural 'chlorophyll' (Tswett 1906a, b, 1910a, b, and references therein). Tswett was a very emotional person and could not easily get along with his colleagues. Therefore, his life was not too happy, especially during the last seven years, which coincided with huge cataclysms in Russian history. However, it is also true that his method was too innovative at that time and was not accepted by researchers during Tswett's lifetime. $\mathrm{He}$ died in Voronez during the civil war, still rather a young man. His grave was restored and is now maintained by nuns of the Voronez St. Alekseevo-Akatov convent (Figure 7).

Lack of a reliable procedure for $\mathrm{Chl}$ isolation hampered decoding of its chemical structure for a long time. In 1851, F. Verdeil in France, then Timiriazeff in Russia (1869-1875) and F. Hoppe-Seyler in Germany (1879-1881) proposed that the chemical structures of hemin and chlorophyll might be similar. Hoppe-Seyler reported that both compounds formed red 'porphyrin' after certain treatment (see references in Timiriazeff 1904; Lubimenko 1910; Lubimenko and Brilliant 1924; Rabinowitch 1951). Serious chemical evidence supporting this idea was obtained at the very end 

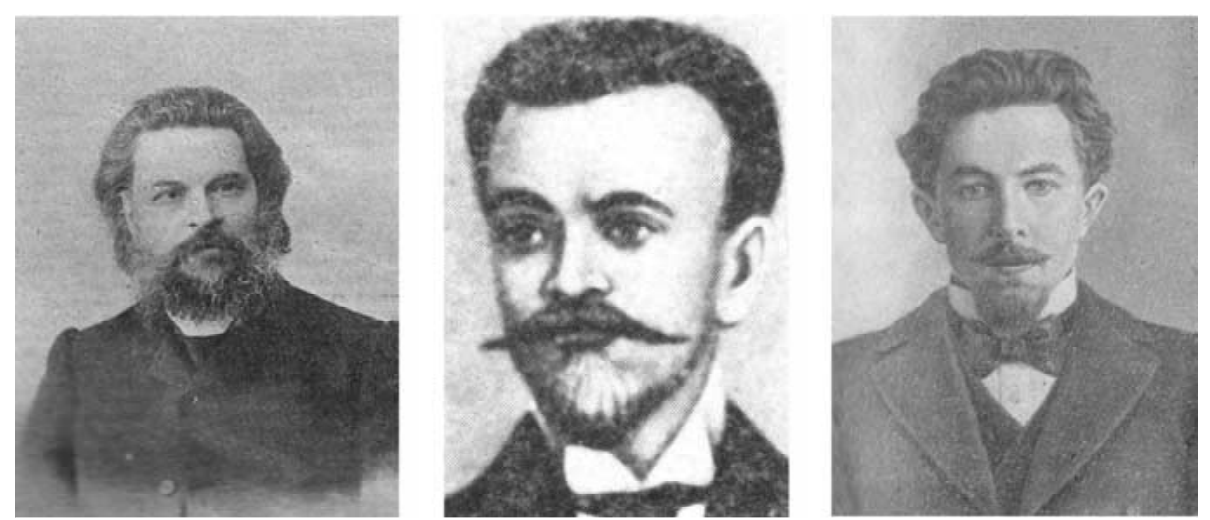

Figure 3 (left). Ivan Parfen'ievitch Borodin (1847-1930). From Komarova (1917). Figure 4 (center). Nikolai Avgustovitch Monteverde (1856-1929). From Volkov (1984). Figure 5 (right). Mikhail Semenovitch Tswett (1872-1919). From Tswett (1946, published posthumously).

of 19 th century by a St. Petersburg biochemist Marcelii Vilgelmovitch Nencki (1847-1901) (Figure 8) and his follower and collaborator Leon Pavel Marchlewski (1869-1946) (Figure 9). Nencki was born in Poland, studied in Germany and graduated from Berlin University. In 1877, at 30 years of age, he became an 'ordinary professor' of physiological chemistry at Bern University. In 1891, he was invited to St. Petersburg as head of the Chemistry Department of the Institute of Experimental Medicine. Marchlewski was born in Poland, studied in Zurich, worked during several years in England and then returned to Poland. Nencki and Marchlewski published many important papers dealing with porphyrin chemistry. In particular, during 1897-1901, they obtained mesoporphyrin, showed that its chemical structure was intermediate between hematoporphyrin and a chlorophyll derivative 'phylloporphyrin' and found that both chlorophyll and hematoporphyrin formed hemopyrrol after certain treatment, which was a mixture of four alkylpyrrols (for references, see Marchlewski's monograph 1909). The sudden death of Nencki in 1901 slowed down this work, which was taken over and brilliantly continued by R. Willstätter and A. Stoll and their coworkers. They succeeded in decoding the basic molecular structure of Chls $a$ and $b$ and also showed that Borodin's crystal-forming pigment was a mixture of methyl- and ethyl-chlorophyllides, which appeared as a result of reaction of native Chl with an enzyme chlorophyllase (Willstätter and Stoll 1913, 1918 and references therein). It is noteworthy that in 1915, Richard Willstätter received the Nobel Prize in Chemistry for the elucidation of the Chl structure and in 1929, he was elected an honorary member of the USSR (Union of Soviet Socialist Republics)
Academy of Science (see Porra, 2002, for Willstätter's photograph).

\section{Protochlorophyll and bacterial chlorophylls}

The process of greening of etiolated leaves was studied in early Famintzin's papers. Timiriazeff described the absorption spectrum of the fluorescing pigment isolated from etiolated leaves. Monteverde continued these studies, proposed to call the pigment 'protochlorophyll' and showed that in leaves protochlorophyll forms chlorophyll upon illumination (Monteverde 1893, 1894 and references therein). After the first decade of the 20th century, Vladimir Nikolaevitch Lubimenko (1873-1937) actively joined in with pigment research. Lubimenko (Figure 10) graduated from the Petersburg Forestry Institute where he was a student and assistant of I.P. Borodin. In 1908, after five years of work in Germany and France (he was especially strongly influenced by Professor Gerbert Bonier in France), he moved to Nikitskii Botanical Garden near Yalta (Crimea), where he organized a botanical-physiological laboratory. He invited Monteverde to collaborate. They found that protochlorophyll concentration is very high in pumpkin seeds and investigated in detail the protochlorophyll absorption spectra in seeds and pigment extracts (Monteverde and Lubimenko 1911a, b, and references therein).

Pigments of purple bacteria were studied by the discoverer of bacterial chemosynthesis Sergei Nikolaevitch Winorgradsky (1856-1953) and recognized microbiologists Georgii Adamovitch Nadson (1866-1940) and Vladimir Martinovitch Arzikhovskii (1876-1931). In 1903 and 1904, Nadson and Arzikhovskii isolated a green pigment from bacterial cells 


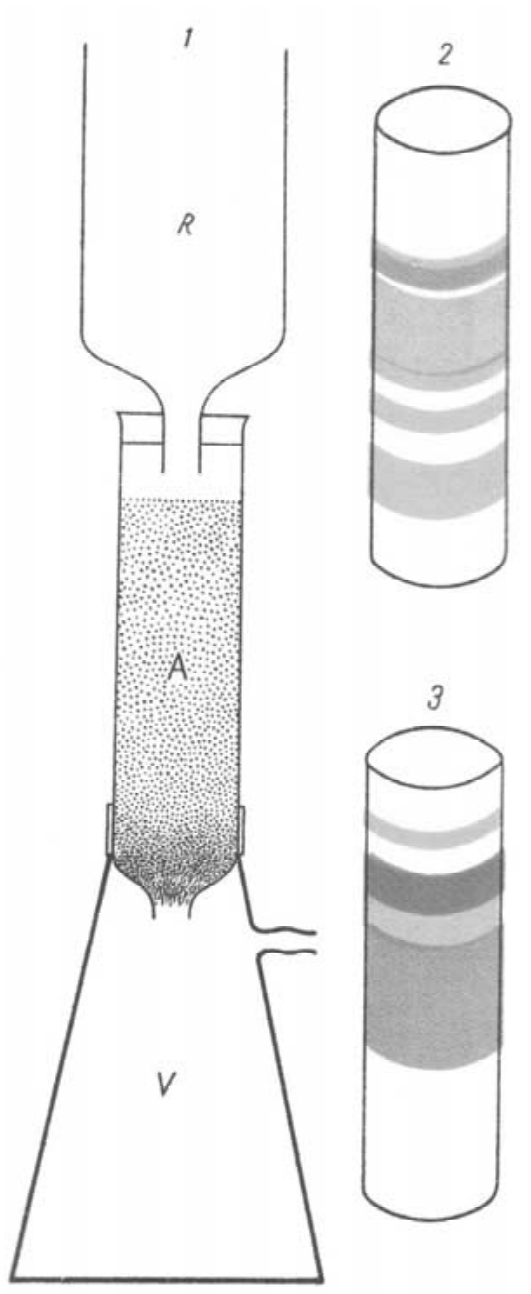

Figure 6. Tswett's chromatograms. 1 - a set up for chromatography separation of pigments; 2 - a chromatogram (a scheme) of normal chlorophyll; 3 - a chromatogram of chlorophyll treated with acid. $\mathrm{R}$ is a flask with a pigment solution, $\mathrm{A}$ is a cylinder with an adsorbing powder, V is a flask connected with an air pump. From Tswett (1910). For a color version of this figure, see color section in the front of the issue.

(Nadson 1903, 1912a; Arzikhovskii 1904). In 1907, a German researcher H. Molish confirmed this observation and proposed to call the green pigment 'bacteriochlorin.' During 1921-1923, Lubimenko investigated the absorption spectra of bacterial pigments in the $400-750 \mathrm{~nm}$ region. He found that the native pigment is blue. It is unstable in the presence of air, and the green pigment is its oxygenation product (Lubimenko and Brilliant 1924 and references therein). A German scientist E. Schneider (1934) and his coworkers established the chemical structure of the blue pigment and proposed to call it 'bacteriochlorophyll.' Nadson

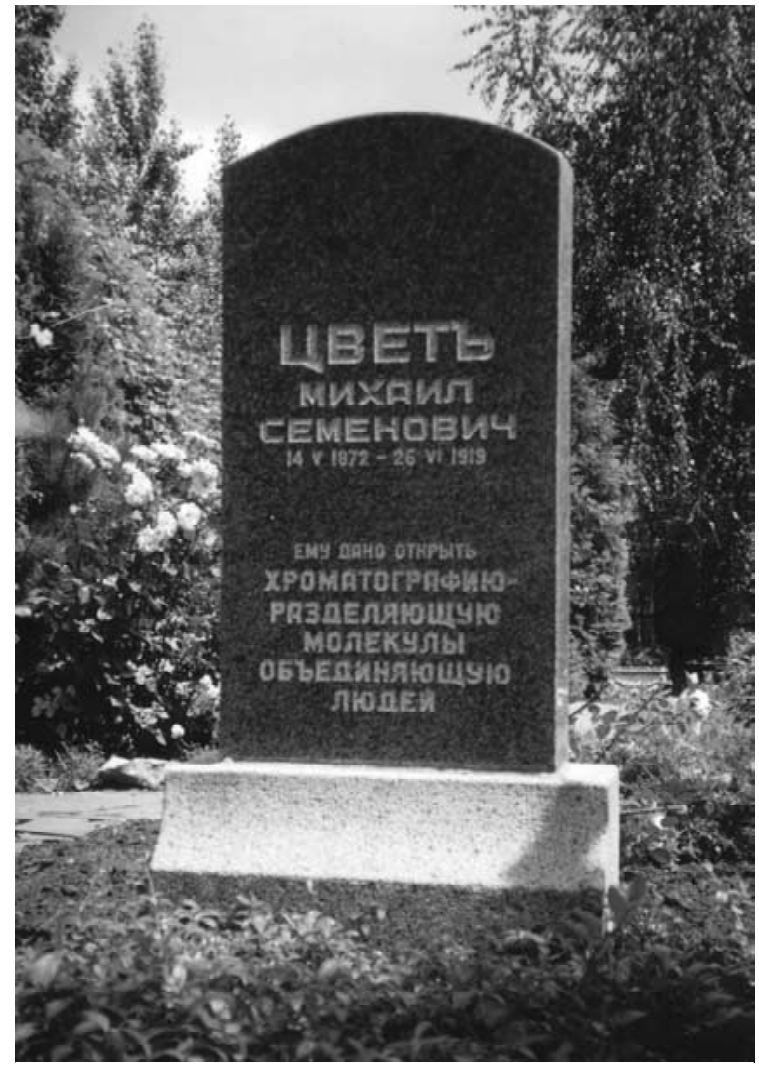

Figure 7. Tswett's grave at the St. Alekseevo-Akatov convent in Voronez. Photo taken by the author.
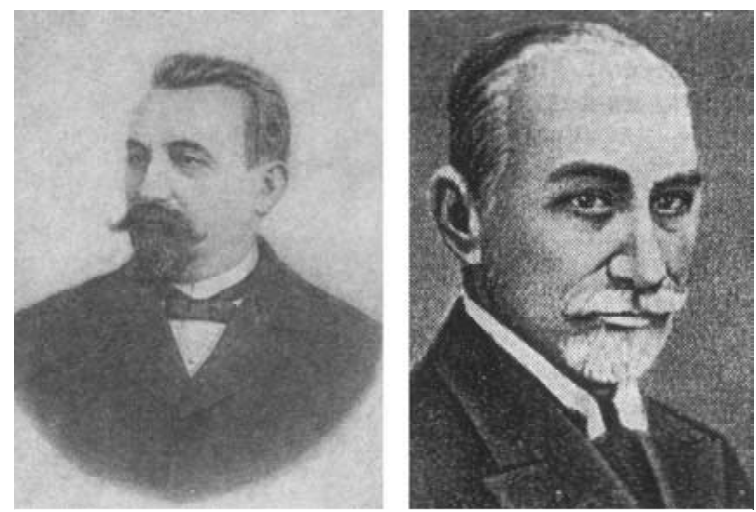

Figure 8 (left). Marcelii Vilgelmovitch Nencki (1847-1901). From Engelgardt (1951). Figure 9 (right). Leon Pavel Teodor Marchlewski (1869-1946). From Volkov (1984).

(1912b) and Monteverde and Perfil'ev (1914) extracted a chlorophyll-like pigment from green bacteria. Its absorption spectrum was similar to that of $\mathrm{Chl} a$, but its chemical properties were different. Lubimenko claimed that the chemical properties of this pigment resemble those of bacteriochlorin (Lubimenko and 


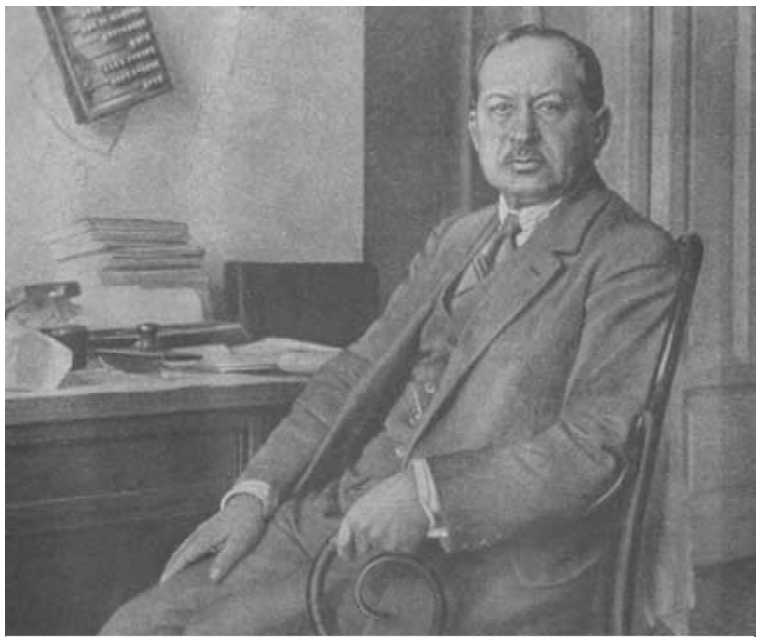

Figure 10 Vladimir Nikolaevitch Lubimenko (1873-1937). From Brilliant (1940).

Brilliant 1924). P. Metzner in Germany supported these observations and proposed to call this pigment 'bacterioviridin' (1922). These data preceded the classical works of E.C. Wassink, E. Katz et al. (1939) and C.S. French (1940), who reported detailed absorption spectra of bacteriochlorophylls of green and purple bacteria in living cells and organic solvents (see Rabinowitch 1951 and references therein).

\section{State of chlorophyll in plants}

It has been known since the 1870 s that the red absorption band of $\mathrm{Chl}$ in leaves is shifted to longer wavelengths as compared to Chl solutions. Timiriazeff wrote about the existence of 'solid chlorophyll' in plants (Timiriazeff 1904). Tswett believed that in situ pigments are absorbed by lipoprotein macromolecules. He also proposed the existence of 'chloroglobin,' a special pigment-lipoprotein complex responsible for the photochemical reactions of photosynthesis (a prototype of the reaction centers) (Tswett 1906, 1910, and references therein). Dmitrii Iosifovitch Iwanowsky (1864-1920), Famintzin's pupil, who is widely known as a discoverer of viruses, began pigment research in 1907 when he moved from St. Petersburg to Warsaw. He observed that the absorption spectra of colloidal chlorophyll solutions, which are formed if water is added to acetone or alcohol extracts of plant pigments, resembled those of chlorophyll in leaves. He proposed that plant pigments are in the colloid state in leaves and that this causes high photostability of chlorophyll in vivo (Iwanowsky 1907, 1913).
Timiriazeff's follower and one of the founders of the Soviet plant physiology school, Vladimir Ivanovitch Palladin (1859-1922), thought that chlorophyll was associated with lipoids (phosphatids) in plants (Palladin 1910). These ideas were widely discussed (Willstätter and Stoll 1913, 1918, and references therein). Tswett and Lubiminko believed that chlorophyll and its bacterial analogs were a part of the native protein-pigment complexes comprising green and yellow pigments. Lubimenko proposed a simple procedure for isolation of this complex from certain plants, based on disintegration of the leaves in cold water followed by filtration of the green material (Lubimenko 1910; Lubimenko and Brilliant 1924).

\section{The transition period (1922-1946)}

The first half of the 20th century was a time of wars and revolutions followed by the destruction of the Russian Empire (1917), civil war, formation of the Soviet Union (1922), a long transition period and then the Second World War (1941-1945). It was also a time of revolutionary discoveries in physics and chemistry. The Soviet Union inherited from old Russia professional plant physiologists, botanists, microbiologists and good specialists in all major branches of the natural sciences. As shown above, the development of chlorophyll research in the Russian Empire was mainly due to the efforts of plant physiologists and biochemists. For further progress, professional chemists and physicists were required. This was mentioned in articles by Alexey Nikolaevitch Bach (1857-1846) (the author of the peroxide theory of slow oxygenation processes), in Timiriazeff's papers and especially in a series of remarkable reviews, which appeared in the 1930s in the Soviet scientific literature (Krasheninnikov 1935; Lubimenko 1935; Brilliant 1937; Nekrasov 1937). The strength of the physico-chemical methods was brilliantly demonstrated in 1941 by the D.I. Vernadsky follower, Alexander Pavlovitch Vinogradov (1895-1975) (Figure 11) and his coworker Rufina Vladimirovna Teis (1896-1986) (Figure 12), who showed, using oxygen isotopes, that photosynthetic oxygen appears as a result of water splitting (Vinogradov and Teis 1941; Vinogradov 1947). This work was done in parallel with that at the University of California (at Berkeley; see Sam Ruben et al. 1941).

In 1945, volume I of a famous book by Eugene I. (Evgenii Isakowitch) Rabinowitch (1901-1973) (Figure 13) 'Photosynthesis and related processes,' ap- 

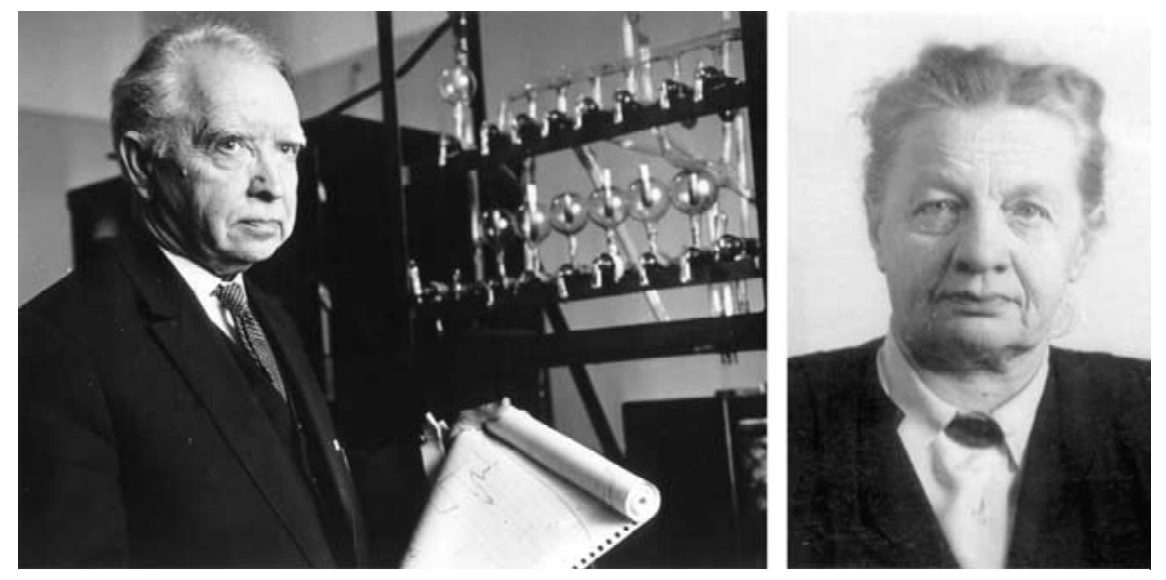

Figure 11 (left). Alexander Pavlovitch Vinogradov (1895-1975). From the archive of the D.I. Vernadsky. Institute of Analytical and Geological Chemistry Russian Academy of Science. Figure 12 (right). Rufina Vladimirovna Teis (1896-1986). Photo taken in the 1970s, from the archive of the D.I. Vernadsky Institute of Analytical and Geological Chemistry RAS.

peared. Though this book was written in the USA it greatly influenced the studies of chlorophyll and photosynthesis in the Soviet Union. Rabinowitch was born and raised in St. Petersburg. Due to the cataclysms caused by the Russian revolution, his family moved to Kiev (Ukraine) when he was about 17 and then to Poland. From Poland Rabinowitch went to Germany, where in 1925 he received his $\mathrm{PhD}$ degree in inorganic chemistry. He then worked with James Franck, which led to the 'Franck-Rabinowitch effect,' also known as 'the cage effect' in photochemistry. In 1933, during the Nazi rule, his fellowship in Germany was cancelled; he then went to Niel Bohr's laboratory in Denmark and from there to the UK. In 1938, he was invited to lecture in the USA and stayed there until his death in 1973 (see Bannister 1972). He knew and loved the Russian language and read and keenly discussed the studies of Soviet researchers. Due to his efforts, Soviet scientists obtained an opportunity to be involved in the world-wide discussion of photosynthesis problems through the 'iron curtain' that was closed at that time. A Russian translation of this book (v. 1) appeared in Moscow in 1951. The translator was Prof. N.D. Leonov and the editor was Prof. A.A. Nichiporowitch. Volume II (part I) (1951) appeared in Russian in 1953 and Volume II (part II) (1956) in 1959.

The 1940s-1950s was also a period of the peak activity of an outstanding scientist Alexander Nikolaevitch Terenin (1896-1967) (Figure 14), who greatly stimulated the development of pigment photochemistry and photophysics in the Soviet Union (Levshin 1985, see also Borisov 2003). He gradu- ated from the Petrograd (St. Petersburg) University in 1922 and than joined the staff of the Chair of Optics and the Optical Institute, where he organized the photochemistry group. Initially, Terenin investigated mercury electronic orbitals and UV-induced dissociation of sodium chloride molecules in a vapor-phase. In 1927, he worked with P. Pringsheim in Berlin and visited many laboratories in Europe. Both Terenin and his supervisor, a recognized physicist, Dmitrii Sergeevitch Rozdestwenskii (1876-1940), believed that the main problem of photochemistry was photosynthesis; therefore, from 1935 Terenin began studies of complex organic molecules. In 1943, a year before G. Lewis and M. Kasha (Lewis and Kasha 1944), Terenin claimed that the metastable phosphorescence state of the dyestuffs is a triplet ('biradical'). He wrote that the lifetime of the triplet state of the dyes was much longer then that of the fluorescence of the dyes. Hence, the steady-state concentration of metastable dye molecules might also be much higher than that of dye molecules in the excited singlet state. Therefore, he agreed with H. Kautsky (1939) and J. Franck (1941) that the metastable state of dyes can be more efficient in the promotion of photochemical reactions than the fluorescence state of dyes (Terenin 1943, 1944). In 1947, Terenin's famous book 'Photochemistry of Dyestuffs' appeared, which, together with the next edition (1967), became a manual for several generations of Soviet photochemists and photobiologists (Terenin 1947a, 1967).

In 1946, at the first All Union Photosynthesis Conference, Terenin presented a remarkable lecture, which was published in 1947. He adopted the idea 

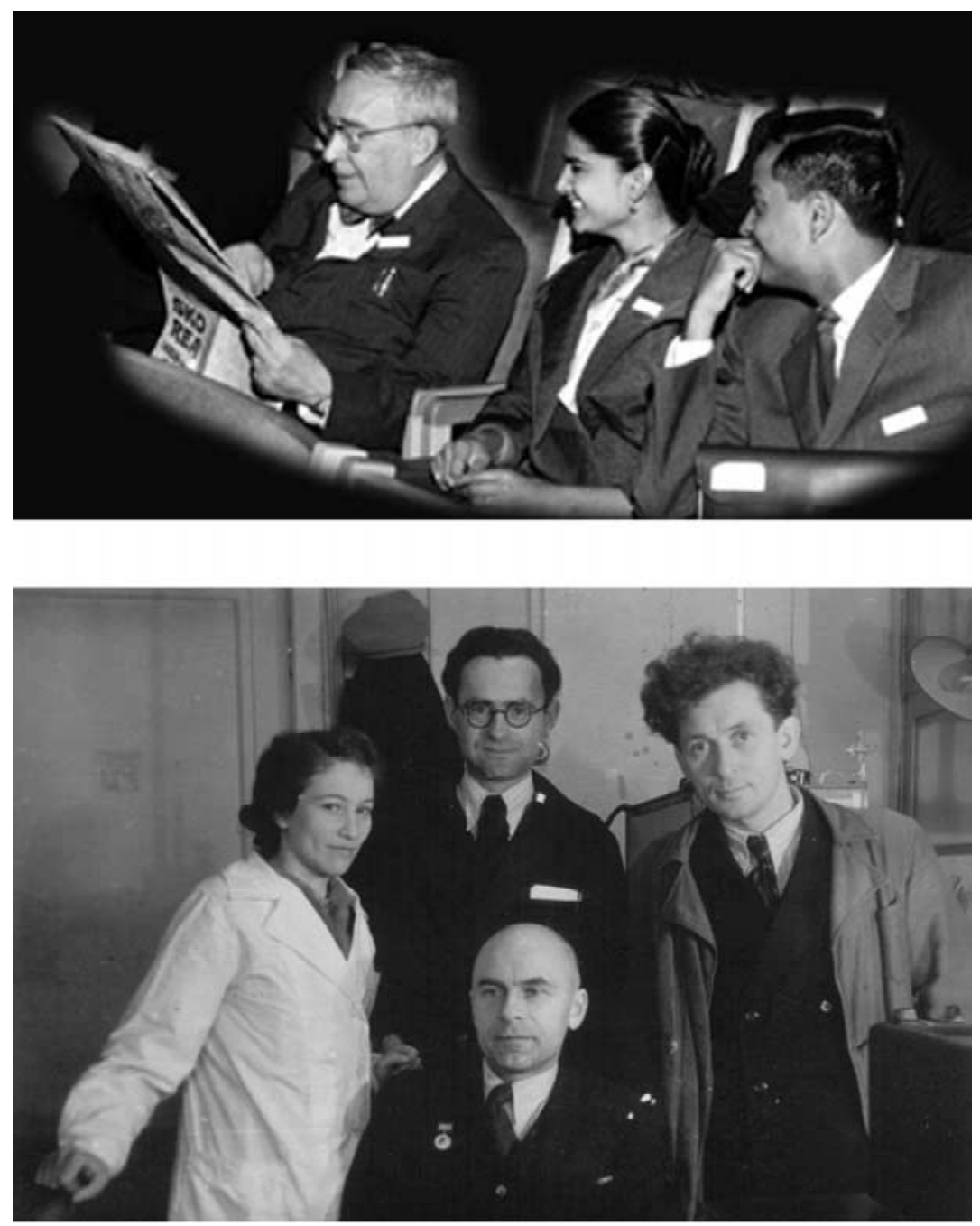

Figure 13 (top). Eugene I. (Evgenii Isakowitch) Rabinowitch (1901-1973) reading a newspaper at the international biophysics congress in Sweden in 1961. To his left are Rajni Varma Govindjee and Govindjee (hand on his face) (photo is a gift from Govindjee).

Figure 14 (bottom). Alexander Nikolaevitch Terenin (sitting), Alexander Abramovitch Krasnovsky (just behind him), Galina Petrovna Brin (woman in white) and Vyacheslav Borisovitch Evstigneev. Photo taken at the Institute of Biochemistry, Moscow, 1946. From the Krasnovsky family archive.

that photosynthesis is a redox photochemical process. Hence, it should be initiated by a redox photosensitizer, which acts in a similar way to the Michaelis mechanism of redox reactions and the primary light driven reaction should be charge (electron) transfer and the primary intermediates - ion-radicals. It should be accompanied by proton translocation, which is a much slower process. He found Szent-Gyorgyi's idea unlikely. Szent-Gyorgyi had proposed that biochemical systems resemble a semiconductor crystal, in which electrons can migrate inside the energy zones. Therefore, Terenin found it highly promising to in- vestigate the roles of both singlet and triplet states as well as free radicals in the photobiochemical reactions, and believed that spectroscopic and fluorescence methods in combination with other methods of physico-chemical analysis were the most useful for this research (Terenin 1947b).

This lecture was actually a presentation of an extensive research program, which Terenin wanted to initiate, and eventually did, in the Soviet Union. From 1945, Terenin began the restoration of his photochemistry laboratory in Leningrad (St. Petersburg), which was destroyed by the War. At the same 
time, he invited a young photochemist Alexander Abramovitch Krasnovsky (1913-1993) (Figure 14) for a doctoral position and the organization of the photobiochemistry laboratory at the Institute of Biochemistry of the USSR Academy of Science in Moscow (Krasnovsky 1992, 1994). The director of the Biochemistry Institute A.N. Bach and vice director V.A. Engelgardt keenly supported this initiative. Terenin and Krasnovsky had been acquainted since 1939, when Krasnovsky worked on his $\mathrm{PhD}$ ('candidate') dissertation at the D.I. Mendeleev Institute of Chemical Technology. Terenin was first an informal adviser and, then, a formal 'opponent' of Krasnovsky's work (Krasnovsky 1992, 1994). The first associates of the photobiochemistry laboratory were Galina Petrovna Brin (1919-1992) (Figure 14), who came in 1945, and Vyacheslav Borisovitch Evstigneev (1909-1977) (Figure 14), who started in 1946. Vera Afanas'evna Gavrilova (1909-1983) and Ksenya Konstantinovna Voinovskaya joined them in 1948-1949, Larisa Mefodievna Kosobutskaya-Vorobyeva, in 1950.

Photochemistry groups also existed in Ukraine and Byelorussia. The Ukrainian group was organized in 1933 by Boris Jakovlewitch Dain (1900-1973) at the Institute of Physical Chemistry of the Ukrainian Academy of Science. Terenin supported its organization and was also an 'opponent' of Dain's doctoral dissertation, which was defended in 1942 in Ufa. This group initially dealt with investigation of the photochemistry of transition metals. After the War, due to the influence of Terenin and Krasnovsky, they began studies of the photochemistry of chlorophyll and porphyrins. Iosif Iosifovitch Dilung headed this group after Dain's retirement.

Tichon Nikolaevitch Godnev (1893-1982) organized the Byelorussian group dealing with the problems of photobiochemistry (Figure 15). He graduated from Moscow University in 1916, where his supervisor was Timiriazeff's pupil Fedor Nikolaevitch Krasheninnikov (1869-1938). After graduation, Godnev moved to the Astrachan University and then to the Ivanovo-Vosnesensk Polytechnical Institute. In 1927, he was invited to Byelorussia and from 1935 worked in both the Byelorussian State University and Byelorussian Academy of Science. He was interested in the biosynthesis and chemistry of chlorophylls and their bacterial analogs. The Minsk school was represented by many outstanding researchers, as for example, Godnev's follower and successor, a recognized biochemist Alexander Arkadievitch Shlyk (1928-1984) and physicists Georgii Pavlovitch Gurinovitch (1933-

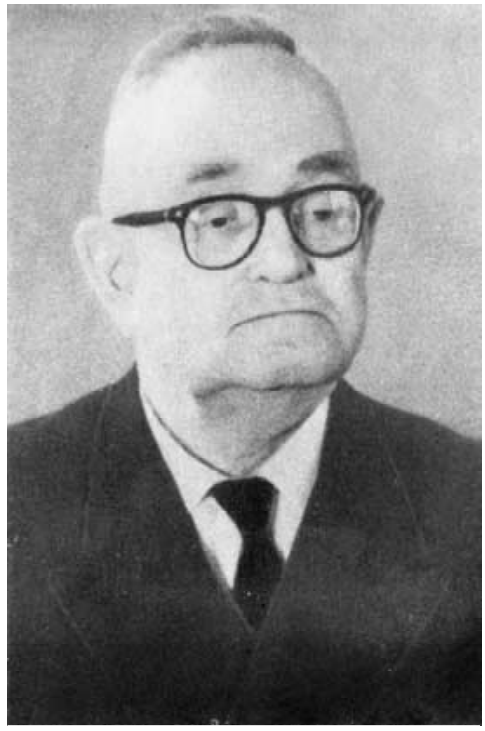

Figure 15. Tichon Nikolaevitch Godnev (1893-1982). From Shlyk (1974).

1994), Konstantin Nikolaevitch Solovyov and their coworkers.

\section{The beginning of growth (1946-1952)}

The photobiochemistry laboratory in Moscow began to work with great energy and productivity. During the first 5 years (1946-1950), the group published 42 experimental papers and 4 reviews (one was written by Terenin, three others by Krasnovsky). Their major goal was to find experimental evidence showing that $\mathrm{Chl}$ and related pigments are capable of reversible photoinduced reduction or oxidation, and that semireduced or semi-oxidized pigment forms can mediate the photosensitized electron transfer. One should remember that flash photolysis and sensitive ESR techniques were not available at that time. The state of the art in this field was described in detail by Rabinowitch (1945). The mechanism of the reversible 'Timiriazeff reaction' seemed not quite certain and this reaction also did not require light. It was known that $\mathrm{Chl}$ photosensitizes the oxygenation of many organic compounds and the reduction of azo dyes or methyl red by phenylhydrazine. However, the elementary mechanisms of these reactions were not understood (see references in Rabinowitch 1945). The most important information about reversible Chl phototransformations was reported by Rabinowitch and Weiss (1936, 1937), Porret and Rabinowitch (1937) and Livingston 
(1941). Rabinowitch and Weiss $(1936,1937)$ showed that if ferric salts were added to a methanol solution of Chl, the solution instantaneously changed its color from green to yellow, and the red absorption band disappeared. The yellow solution could be changed back into the green form after the addition of ferrous chloride or another reductant. Discoloration of Chl by ferric ions was accelerated by light. Rabinowitch and Weiss suggested that the reaction of $\mathrm{Chl}$ with ferric ions was a reversible $\mathrm{Chl}$ oxidation and photooxidation. Later, Rabinowitch reported that if a low concentration of ferric ions was used, which did not cause marked discoloration of $\mathrm{Chl}$ in the dark, reversible light-induced Chl bleaching was observed in methanolic solutions. This photoreaction was not inhibited by oxygen, but the degree of bleaching was as low (about 1\%) as in Chl solutions, which did not contain ferric salts (Rabinowitch 1945). Though these observations were very important, the reaction mechanisms did not seem quite clear at that time. Rabinowitch wrote that 'additional proof seems to be needed to establish the correctness of this interpretation' and also presented arguments in favor of alternative mechanisms (Rabinowitch 1945). Porret and Rabinowitch (1937) and Livingston (1941) observed reversible photobleaching of $\mathrm{Chl}$ in air-free methanol. The reaction was strongly enhanced in the presence of formic acid and inhibited by very low oxygen concentrations (about $10^{-6} \mathrm{~m}$ ). However, it remained unclear whether this reaction was an example of the primary photoreduction or primary photooxidation of Chl.

Krasnovsky started from an attempt to observe reversible Chl photooxidation using air oxygen or benzoyl peroxide as oxidizing agents. It was shown that intermediate photoproducts were formed, which reacted with a reductant, ascorbic acid, with partial restoration of the initial Chl (Krasnovsky 1947a, b). The degree of reversibility was low. In 1948, Krasnovsky discovered fully reversible Chl photoreduction by ascorbic acid or phenylhydrazine ('Krasnovsky reaction'). This reaction was first observed in Chl solutions in pyridine and in ethanol containing pyridine or ammonium. The spectrum of photoreduced $\mathrm{Chl}$ presented in the first paper by Krasnovsky is shown in Figure 16. The reaction did not proceed in the dark and returned to the regeneration of initial $\mathrm{Chl}$ when the light was turned off. The back reaction was strongly accelerated by oxygen (Krasnovsky 1948). Then, this reaction was observed in pyridine-water mixtures and some other solvents in the presence of different electron donors (Krasnovsky et al. 1949).
Evidence was also obtained that $\mathrm{Chl}$ photosensitizes electron transfer from ascorbic acid to nicotinamide adenine dinucleotide (NAD) in the solution-phase and that reduced $\mathrm{Chl}$ can transfer hydrogen (electrons) to appropriate acceptors (including NAD) in the dark (Krasnovsky and Brin 1949, 1950). In 1949, reversible photoreduction of protochlorophyll (Krasnovsky and Voynovskaya 1949); in 1950, reversible photoreduction of pheophytin (Evstigneev and Gavrilova 1950); and in 1951, reversible photoreduction of bacteriochlorophyll and bacteriopheophytin (Krasnovsky and Voynovskaya 1951) were observed. In order to study the roles of Chl singlet and triplet states, Evstigneev and Krasnovsky investigated the quenching of $\mathrm{Chl}$ fluorescence by electron donors and electron acceptors. They found that oxygen and p-benzoquinone strongly quenched, while the reducing agents, hydroquinone, ascorbic acid, $\mathrm{KI}$ and $\mathrm{NaI}$ did not quench Chl fluorescence (Evstigneev and Krasnovsky 1948). In 1950, a more detailed study was reported. It was shown that though quinone causes strong fluorescence quenching, no photoreaction was observed between $\mathrm{Chl}$ and quinone in pigment solutions. On the contrary, ascorbic acid, which does not quench $\mathrm{Chl}$ fluorescence, causes efficient photoreaction. These observations led to the conclusion that the triplet state is responsible for photoreduction of the pigments (Evstigneev et al. 1950). Terenin thought that quenching of dye fluorescence by electron acceptors and donors also reflects a reversible photochemical reaction, which involves a rapid electron exchange between the quenchers and the excited singlet states of dye molecules and does not lead to long-lived reaction products (Terenin 1947a). Though certain mechanistic details remained unclear, in 1950-1962, the 'Krasnovsky reaction' was the most convincing example of reversible redox phototransformations of $\mathrm{Chl}$; it therefore attracted the attention of many researchers. In the Soviet Union, its significance was especially high, because it correlated with traditional Timiriazeff's ideas, supported Terenin's views on the importance of the triplet state in photochemistry and provided a very simple tool for investigation of Chl photoreactions and photosynthesis.

Evstigneev and Terenin (1951) applied a photoelectric method to elucidate the primary photoreaction of Chl, pheophytin and phthalocyanine. They prepared pigment films on the surface of a platinum electrode immersed in a saturated aqueous solution of $\mathrm{KCl}$ and measured its electrical potential as compared to a calomel reference electrode. If oxidants (oxygen or 


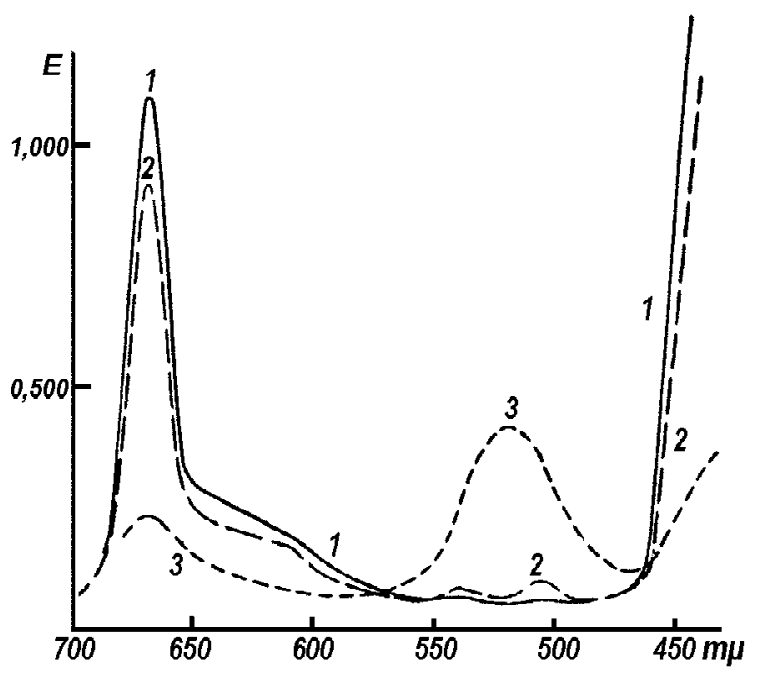

Figure 16. Reversible photochemical reduction of chlorophyll (Chl) $a$ in pyridine by ascorbic acid. 1 - the absorption spectrum of initial chlorophyll; 2 - the absorption spectrum of $\mathrm{Chl}$ after reverse reaction; 3 - an approximate spectrum of a labile photoproduct 6 min after the end of illumination ( $E$ is the optical density, precision of the $E$ values was $\pm 10 \%$ ). From Krasnovsky (1948).

$p$-benzoquinone) were added to the solution, illumination of pigment films caused a positive shift of the charge of the Pt electrode. If reductants (hydrosulfite, hydroquinone or ascorbic acid) were added, the charge was shifted to the negative side. This experiment showed that Chl was capable of both photoinduced oxidation and reduction, which was consistent with the 'Rabinowitch-Weis' and 'Krasnovsky' reactions.

In 1950, Dain's group in Kiev joined the Chl photochemistry research. In 1950 and in a series of subsequent papers, they reported that the RabinowithWeiss reaction might be more complicated than the authors had suggested, because it was accompanied by the formation of pheophytin, complexes of Chl with iron salts and irreversible replacement of magnesium by iron (Ashkinasi et al. 1950; Butzko and Dain 1958). The contribution of these processes was also already discussed by Rabinowitch in volume I of his book (1945). For more detailed discussion of the reaction mechanisms, see a review by Gilbert Seely (1977).

In 1951, Dain's group reported on a very important reversible reaction that was observed after illumination of the Chl solutions in ethanol or ethanol-ether (1:3) by UV-light at liquid air temperature. Upon UV-light exposure, the red Chl absorption band disappeared and then returned after melting. The effect was interpreted as photooxidation of pigment molecules due to trapping of electrons by solvents. The reaction was not observed under red light (Kachan and Dain 1951). H. Linshitz and J. Renert (1952) found similar reversible $\mathrm{Chl}$ photobleaching at $-190{ }^{\circ} \mathrm{C}$ in glassy solvents under both blue and red light and showed that this effect was strongly enhanced after the addition of quinone or imine. Bleaching of $\mathrm{Chl}$ absorption bands was accompanied by an increase of absorption in the green and dark red regions. These papers showed that fully reversible Chl photooxidation by quinones might be observed at low temperature. However, unambiguous experimental proof of the existence of such a reaction was obtained 10 years later in parallel experiments by G. Tollin and G. Green (1962), who used low-temperature ESR measurements, and Krasnovsky and Drozdova $(1963,1964)$ who used low-temperature spectroscopic measurements. The latter authors also showed for the first time that bacteriochlorophyll undergoes reversible photooxidation by quinone. The reversible photoxidation of $\mathrm{Chl}$ by quinone at room temperature was only observed in 1967, using the flash photolysis technique (Chibisov et al 1967). (See also J. Fajer, Part 3 of the history issues, forthcoming, for discussions on spectra of oxidized $\mathrm{Chl}$ in solutions and in reaction centers.)

During 1949-1952, Krasnovsky and his coworkers began to explore the problem of the Chl state in plants. They repeated Iwanowsky's measurements of the absorption spectra of the pigments in colloidal solutions (Iwanowsky 1907, 1913) and compared them with the absorption spectra of pigments in solid films and living organisms (Krasnovsky and Brin 1948; Krasnovsky and Kosobutskaya 1952; Krasnovsky et al. 1952). The experiments with bacteriochlorophyll $a$ were the most successful (Figure 17). It was found that the absorption maximum of aggregated bacteriochlorophyll resembles that of $\mathrm{BChl}$ in cells of photosynthetic bacteria and is strongly shifted to the longer wavelengths (to $850 \mathrm{~nm}$ ) as compared to monomeric pigment (790 $\mathrm{nm})$. Therefore, it was concluded that the pigmentpigment interactions might play a major role in the spectral properties of the pigments in the photosynthetic apparatus.

The papers of 1946-1952 ended the transition period and started a period of explosive growth of research in photosynthesis in the Soviet Union. The photobiochemistry laboratory, headed by Krasnovsky, became a leader of chlorophyll research in the Soviet Union. Investigation of reversible photoreduction and reversible photooxidation of chlorophylls, bacteriochlorophylls, protochlorophyll, pheophytins 


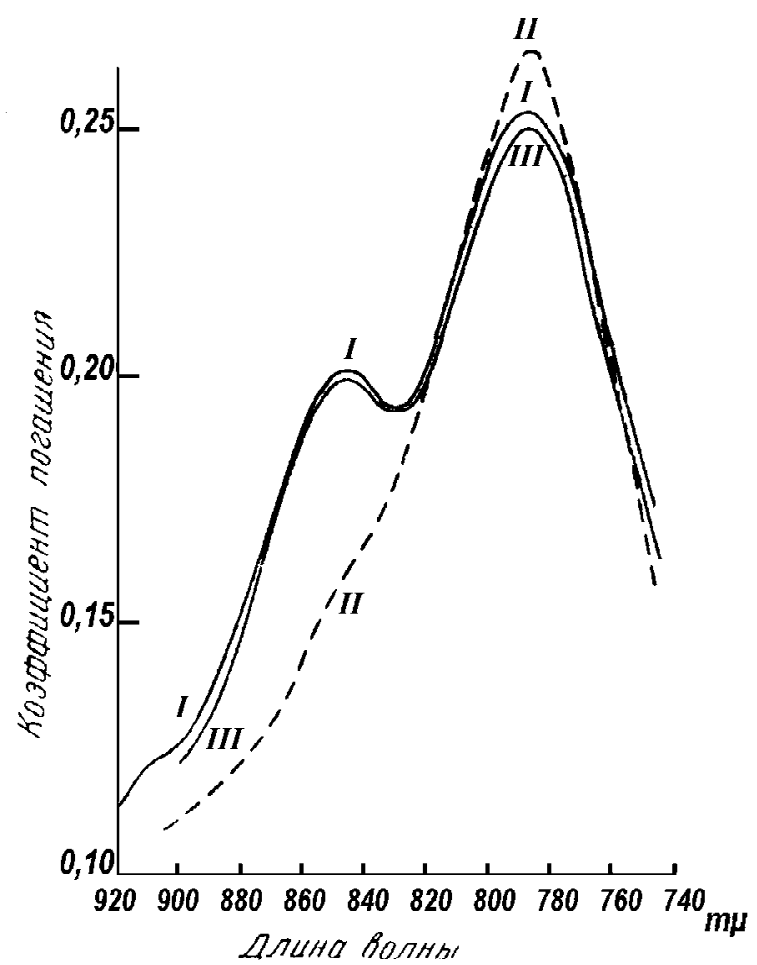

Figure 17. Absorption spectrum of the bacteriochlorophyll (BChl) solid films measured at $20^{\circ} \mathrm{C}$. I - a film obtained by evaporation of the $\mathrm{BChl}$ solution in ether; II - the same after heating to $60^{\circ} \mathrm{C}$; III - after cooling to $5^{\circ} \mathrm{C}$ and $45 \mathrm{~min}$ storage at this temperature. From Krasnovsky et al. (1952).

and related pigments, as well as studies of pigmentphotosensitized electron transfer, pigment-pigment interactions, photochemistry and spectroscopy in pigment solutions and model systems and in plant and bacterial cells became the main direction of further research. The major landmarks of the growth period were partially reflected in Krasnovsky's recollections (1992, 1994) (also see O. Belyaeva, A. Borisov and V. Klimov, this issue, for research on other aspects of photosynthesis in Russia).

\section{Concluding remarks}

This paper stops at 1952, which was half a century ago. At that time, researchers did not have good methods for the physicochemical analysis of Chl reactions in the photosynthetic apparatus and focused their effort on models based on Chl solutions. Modern scientists are armed with fast time-resolved methods based on the use of nanosecond, picosecond and even femtosecond lasers, sensitive differential spec- trophotometers, sensitive fluorimeters, Electron Spin Resonance (ESR) and Fourier Transform Infra Red (FTIR) spectrometers, low temperature techniques, Xray structural analysis and well developed biochemical methods of isolation of active structural fragments from the photosynthetic apparatus. Therefore, many researchers prefer to deal with isolated fragments of the photosynthetic apparatus, or living cells. Studies of Chl solutions are now much less popular. Application of the above-mentioned arsenal allowed the resolution of many problems that could not be resolved in earlier times. One of these problems is the role of singlet and triplet states in photosynthesis. As discussed above, the photochemistry of Chl solutions was initiated by the Chl triplet state. In the photosynthetic apparatus, photoinduced electron transport is promoted by the the singlet states of the reaction center $\mathrm{Chl}$, while the $\mathrm{Chl}$ triplet states, which are also formed, generate singlet oxygen and are responsible for photodestruction and photoinhibition (see, for example, Krasnovsky Jr., 1994, and references therein). A concept that redox photoreactions of $\mathrm{Chl}$ promote the process of photosynthesis via intermediate formation of ion-radicals, which was brilliantly demonstrated on Chl solutions, was fully confirmed by modern studies and many new details were revealed. In particular, it was shown that primary photooxidation of reaction center $\mathrm{Chl}$ is more important than its primary photoreduction for photosynthetic electron transport. An idea that pigmentpigment interaction governs the spectral properties of pigments in living cells is shown to be correct in some cases. However, the pigments are associated with proteins in the photosynthetic apparatus and therefore their spectral properties are strongly influenced by the protein carriers. At any rate, the results of the research work of early years mentioned in this paper laid down the basics upon which current concepts of photosynthesis are built. Thus, the seminal work of our predecessors deserves high respect and acknowledgement.

\section{Acknowledgments}

The author thanks Govindjee for the invitation to write this review, for his plentiful and useful advice, and for the general editing of the manuscript, Felix Fedorovich Litvin for his approval of and kind interest in this work and Andrey Borisovich Rubin for his stimulating support of the idea of such a review. I also acknowledge Prof. Iosif I. Dilung for information 
regarding photochemistry research in Ukraine and also the staff of the D.I. Vernadsky Institute of Analytical and Geological Chemistry of the Russian Academy of Science for photographs of A.P. Vinogradov and R.V. Teis.

This work was supported by the Russian Foundation for Basic Research.

\section{References}

Arzikhovskii VM (1904) On the problem of bacteriopurpurin. Izy St Petersb Bot Sada [Bulletin of the St Petersberg Botanical Garden] 4: 81-85 [in Russian]

Ashkinasi MS, Glikman GS and Dain BYa (1950) On the nature of chlorophyll reactions with inorganic ions. Dokl AN SSSR 73: 743-746

Babii TP, Kochanova LL, Kostiuk GG, Zadoroznii AG, Matveenko SA, Pogrebniyak LP, Teplitskaya EV and Trukhanov VA (1984) Biologists. Biography Vocabulary. 'Naukova Dumka' Publ, Kiev

Bannister TT (1972) The careers and contributions of Eugene Rabinowitch. Biophys J 12: 707-718

Belyaeva OB (2003) Studies of chlorophyll biosynthesis in Russia. Photosynth Res 76: 405-411 (this issue)

Borisov AYu (2003) The beginnings of research on biophysics of photosynthesis and initial contributions made by Russian scientists to its development. Photosynth Res 76: 413-426 (this issue)

Borodin IP (1881) On the chlorophyll crystals. Trudy St. Petersb Obschestva Estestvoispytateley [Works of the St Petersberg Society of Naturalists] 12: 137-144 [in Russian]

Borodin IP (1882) Über Chlorophyllkristalle. Bot Z 40(36): 608610

Brilliant VA (1937) The newest data of the photosynthesis research. Uspekhi Sovrem Biologii [Modern Biology Reviews] 6: 193234 [in Russian]

Brilliant VA (ed) (1940) Experimentalnaya botanika [Experimental Botany] 4: 6 [in Russian]

Brokhauz FA and Effron IA (1899) Encyclopedic Vocabulary St Petersburg 26: 390-391

Butsko SS and Dain BYa (1958) Spectrophotometric study of chlorophyll interaction with ferric chloride. Zhur Obschei Khim [Soviet Journal of General Chemistry] 28: 2603-2612

Chibisov AK, Karyakin AV, Drozdova NN and Krasnovsky AA (1967) Investigation of the intermediate states in reaction of photooxidation of chlorophyll and its analogs by p-quinone. Dokl AN SSSR 175: 737-740

Engelgardt VA (1951) M.V. Nencki. Biokhimia [Biochemistry (Moscow)] 16: 486-494

Evstigneev VB and Gavrilova VA (1950) Comparison of photochemical properties of chlorophyll, pheophytin, phthalocynine and its magnesium complex. Dokl AN SSSR 84: 781-783

Evstigneev VB and Gavrilova VA (1956) On the reversibility of the Timiriazeff reaction and on the relation between dark and photochemical reduction of chlorophyll and its analogs. Dokl AN SSSR 108: 507-510

Evstigneev VB and Krasnovsky AA (1948) Quenching of fluorescence of magnesium phthalocyanine and chlorophyll by foreign molecules. Dokl AN SSSR 60: 623-626
Evstigneev VB and Terenin AN (1951) Photoelectrochemical effects of phthalocyanines, chlorophyll and pheophytin. Dokl AN SSSR 60: 623-626

Evstigneev VB, Gavrilova VA and Krasnovsky AA (1950) On the quenching of fluorescence of chlorophyll and phthalocyanine and their interaction with quenching compounds. Dokl AN SSSR 74: 315-318

Famintzin AS (1867-1868) Die Wirkung des Lichtes auf das Engrünen der Pflanzen. Bull Acad Imperial Sci St Petersburg 6: $45-48$

Franck J (1941) Remarks on fluorescence, phosphorescence and photochemistry of dyestuffs. J Chem Phys 9: 184-190

Godnev TN and Kalishevitch SV (1945) On leucochlorophyll and protochlorophyll. Trudy Inst Fiziol Rastenij [Works of the Institute of Plant Physiology] 2: 160-167 [in Russian]

Iwanowsky DI (1907) Über die Ursache der Verschiebung der Absorptionsbänder im Blatt. Ber Deutsch Bot Gesellshaft 25: 416-424

Iwanowsky DI (1913) Kolloidales Chlorophyll und die Verschiebung der Absorption-bänder in lebenden Pflanzenblättern. Biochem Z 58: 328-331

Kachan AA and Dain BYa (1951) Photochemistry of chlorophyll at liquid air temperature. Dokl AN SSSR 80: 619-622

Kautsky H (1939) Quenching of luminescence by oxygen. Trans Farad Soc 35: 216-219

Klimov VV (2003) Discovery of pheophytin function in the photosynthetic energy conversion as the primary electron acceptor of Photosystem II. Photosynth Res 76: 247-253 (this issue)

Komarova VL (1917) I.P. Borodin. Priroda [Nature] 6 (February): 227-238

Kosobutskaya LM and Krasnovsky AA (1950) The study of products of reduction of chlorophyll, its derivatives and analogs by Timiriazeff reaction. Dokl AN SSSR 74: 103-106

Kracheninnikoff FN (1935) The newest data on the carbohydrate photosynthesis. Uspekhi Khimiii [Chemistry Reviews] 4: 138164

Krasnovsky AA (1947a) On the photochemical oxidation of magnesium phthalocyanine and chlorophyll. Dokl AN SSSR 58: $617-620$

Krasnovsky AA (1947b) On the reversibility of oxidation of chlorophyll and magnesium phthalocyanine by benzoyl peroxide. Dokl AN SSSR 58: 835-837

Krasnovsky AA (1948) Reversible photochemical reduction of chlorophyll by ascorbic acid. Dokl AN SSSR 60: 421-424

Krasnovsky AA (1992) Excited chlorophyll and related problems. Photosynth Res 33: 177-192

Krasnovsky AA (1994) A lifetime journey with photosynthesis. Compr Biochem 40: 205-251

Krasnovsky AA and Brin GP (1948) Optical and photochemical properties of chlorophyll in different types of bonding. Dokl AN SSSR 63: 163-165

Krasnovsky AA and Brin GP (1949) Hydrogen transfer from ascorbic acid to codehyrase I under action of light absorbed by chlorophyll. Dokl AN SSSR 67: 325-328

Krasnovsky AA and Brin GP (1950) Reactions of the photoreduced chlorophyll form. Dokl AN SSSR 68: 1239-1242

Krasnovsky AA and Drozdova NN (1963) Reversible photochemical interaction of chlorophyll, bacteriochlorophyll and bacterioviridin with quinone and oxygen in the alcohol-glycerol solution. Dokl AN SSSR 150: 1378-1380

Krasnovsky AA and Drozdova NN (1964) Reversible photochemical oxidation and reduction of chlorophyll, bacteriochlorophyl and bacterioviridin in the viscous medium; differential absorption spectra of intermediate forms. Dokl AN SSSR 158: 730-733 
Krasnovsky AA and Kosobutskaya LM (1952) Spectral study of the chlorophyll state in plants and in colloid solutions of the substance of etiolated leaves. Dokl AN SSSR 85: 177-180

Krasnovsky AA and Voynovskaya KK (1949) Photochemical properties of protochlorophyll. Dokl AN SSSR 66: 663-666

Krasnovsky AA and Voynovskaya KK (1951) Reversible photochemical reduction and oxidation of bacteriochlorophyll and bacteriopheophytin. Dokl AN SSSR 81: 879-882

Krasnovsky AA, Brin GP and Voynovskaya KK (1949) Conditions for reversible transformations of chlorophyll occuring upon light action. Dokl AN SSSR 69: 393-396

Krasnovsky AA, Voynovskaya KK and Kosobutskaya LM (1952) The nature of the state of bacteriochlorophyll in living cells in connection with the spectral properties of its colloid solutions and solid films. Dokl AN SSSR 85: 389-392

Krasnovsky AA Jr (1994) Singlet oxygen and primary mechanisms of photoxidative damage of chloroplasts. Studies based on detection of oxygen and pigment phosphorescence. Proc R Soc Edinburgh 102B: 219-235

Kursanov AL (ed) (1967) The History and Modern State of Plant Physiology at the Academy of Science. Nauka, Moscow [in Russian]

Kuznetsov VV and Stroganov BP (1995) Patriarch of the Russian plant physiology. Russ Plant Physiol 42: 341-347

Levshin LV (1985) Alexander Nikolaevitch Terenin. Nauka, Moscow [in Russian]

Lewis GM and Kasha M (1944) Phosphorescence and the triplet state. J Am Chem Soc 66: 2100-2116

Linshitz H and Renert J (1952) Reversible photobleaching of chlorophyll in rigid solvents. Nature (London) 169: 193-194

Livingston R (1941) The reversible bleaching of chlorophyll. J Phys Chem 45: 1312-1320

Lubimenko VN (1910) Concentration of chlorophyll in chlorophyll grain and energy of photosynthesis. Trudy St Petersb Obschestva Estestvoispytateley [Works of the St Petersburg Society of Naturalists] 41: 1-266 [in Russian]

Lubimenko VN (1935) Photosynthesis and chemosynthesis in the plant world. Selchozgis, Moscow/Leningrad [in Russian]

Lubimenko VN and Brilliant VA (1924) The color of plants. Plant pigments. Gosizdat, Leningrad [in Russian]

Lunewsky T (1870) On chlorophyll. Works of the Physiol. Laboratory of Warsaw University [in Russian]

Marchlewski LP (1909) Die Chemie des Chlorophylle und ihre Beziehung zur Chemie des Blutfarbstoff. F Vieweg und Sohn, Braunschweig

Metzner P (1922) Studien über den Farbstoff der grünen Bakterien. Ber Deutsch Bot Ges 40: 125-148

Molisch H (1907) Die purpurbakterien nach neuen Untersuchungen. University of Jena, Jena

Monteverde NA (1893) Das Absorptions spectrum des Chlorophylls. Acta Horti Petropolitani 13: 121-178

Monteverde NA (1894) Ueber das Protochlorophyll. Acta Horti Petropolitani 13: 201-217

Monteverde NA and Lubimenko VN (1911a) Untersuchungen über die Chlorophyllbildung bei den Pflanzen. Biolog Centralbl 31: $449-458$

Monteverde NA and Lubimenko VN (1911b) Untersuchungen über die Chlorophyllbildung bei den Pflanzen. Biolog Centralbl 31: 481-498

Monteverde NA and Perfili'ev BV (1914) On a chlorophyll-like pigment of 'green bacteria' Pelodietyon. Zhurnal Mikrobiologii [Journal of Microbiology] 1: 199-207
Nadson GA (1903) Observations on the purple bacteria. Izv St Petersburg Bot Sada [Bulletin du Jardin Impérial Botanique de St Pétersburg] 3: 99-103 [in Russian]

Nadson GA (1912a) On the color and pigments of purple bacteria. Izv St Peterburg Bot Sada [Bulletin du Jardin Impérial Botanique de St Petersburg] 12: 73-81 [in Russian]

Nadson GA (1912b) Chlorobium limicola Nads, the green microorganism with non-functioning chlorophyll. Izv St Peterburg Bot Sada [Bulletin du Jardin Impérial Botanique de St Petersburg] 12: 55-73 [in Russian]

Nekrasov NI (1937) Physicochemical concepts of photosynthesis. Uspekhi Khimii [Chemistry Reviews] 6: 315-379 [in Russian]

Palladin WI (1910) Zur Physiologie der Lipoide. Ber Deutch Bot Ges 28(5): 120-125

Porret D and Rabinowitch EI (1937) Reversible bleaching of chlorophyll. Nature 140: 321-322

Porra RJ (2002) The chequered history of the development and use of simultaneous equations for the accurate determination of chlorophylls $a$ and $b$. Photosynth Res 73: 149-156

Rabinowitch EI (1945) Photosynthesis and Related Process. Volume 1, Interscience Publishers, New York

Rabinowitch EI (1951) Photosynthesis and Related Process. Volume 2, part 1. Interscience Publishers, New York

Rabinowitch EI (1956) Photosynthesis and Related Process. Volume 2, part 2. Interscience Publishers, New York

Rabinowitch EI and Weiss J (1936) Reversible oxidation and reduction of chlorophyll. Nature 138: 1098-1099.

Rabinowitch EI and Weiss J (1937) Reversible oxidation of chlorophyll. Proc R Soc London Ser A 162: 251-267

Ruben S, Randall M, Kamen M and Hyde JJ (1941) Heavy O (O $\left.{ }^{18}\right)$ as tracer in study of Photosynthesis. J Am Chem Soc 63: 877880

Seely GR (1977) Chlorophyll in model systems: clues of the role of chlorophyll in phoptosynthesis. In: Barber J (ed) Primary Processes of Photosynthesis, pp 2-52. Elsevier/North-Holland Biomedical Press, Amsterdam

Schneider E (1934) Über das Bakteriochlorophyll der Purpurenbakterien. Hoppe-Seylers L Phys Chem 2: 26-221

Shlyk AA (ed) (1974) Chlorophyll. Nauka i Technika, Minsk [in Russian]

Terenin AN (1943) Photochemical process in aromatic compounds. Acta Physicochim USSR 18: 210-241

Terenin AN (1944) Photochemical processes in aromatic compounds. Sov J Phys Chem 17: 1-12

Terenin AN (1947a) Photochemistry of Dyes and Related Organic Compounds. Publishing House of the USSR Academy of Science, Leningrad [in Russian]

Terenin AN (1947b) Major problems of photobiochemistry. Bull USSR Acad Sci Ser Biol 3: 369-376

Terenin AN (1967) Photonics of dye molecules and related organic compounds. Nauka, Leningrad

Timiriazeff CA (1869) Über die Resultate einer Spectral-Analyse des Chlorophylls. Bot Z 27: 884-885

Timiriazeff CA (1871) Spectral analysis of chlorophyll. The magister dissertation, St Petersburg University, St. Petersburg [in Russian]

Timiriazeff CA (1904) The cosmical function of green plants. Proc R Soc London 72: 424-461

Timiriazev CA (1923) Sun, Life and Chlorophyll. Collection of research papers, speeches and lectures for 1868-1920. Gosizdat, Moscow [in Russian] [published posthumously]

Timiriazeff CA (1948) Selected Papers on Chlorophyll and Assimilation of Light by Plants. The USSR Academy of Science, Moscow [republished posthumously] 
Tollin G and Green G (1962) Light-induced single electron transfer reactions between chlorophyll $a$ and quinones in solutions. Biochim Biophys Acta 60: 524-538

Tswett MS (1906a) Physikalish-chemische Studien über das Chlorophyll. Die Absortionnen. Ber Deutch Bot Ges 24: 316323

Tswett MS (1906b) Absorbtionsanalyse und chromatographische Methode. Anwendung auf die Chemie des Chlorophylls. Ber Deutsch Bot Ges 24: 384-393

Tswett MS (1910a) Chromophylls in Plant and Animal Worlds. Warsaw University, Warsaw [in Russian]

Tswett MS (1910b) Das sogenam 'Kristallisierte' Chlorophyll in Gemisch. Ber Deutsch Chem Ges 43: 3119-3141

Tswett MS (1946) Chromatography adsorption analysis. Selected papers. Publisher of the USSR Academy of Science, Moscow [in Russian] [republished posthumously]
Vinogradov AP (1947) Geochemical history of oxygen and photosynthesis. Bull USSR Acad Sci Ser Biol 3: 409-422

Vinogradov AP and Teis RV (1941) Isotopic composition of oxygen from different sources Dokl AN SSSR 33: 497-501

Volkov VA, Vonskii EV and Kuznetzova GI (1984) Chemists: Biography, Vocabulary. Naukova Dumka, Kiev

Willstätter R and Stoll A (1913) Untersuchungen über Chlorophyll. Springer, Berlin

Willstätter R and Stoll A (1918) Untersuchungen über Assimilation of Kohlensäure. Springer, Berlin

Wolkoff AN (1866) Einige Untersuchingen ueber die Wirkung des Lichtes von verschiender Intensitat auf die Ausscheidung der Gaze durch Wasserpflanzen. Jahrbuch Wiss Bot 5: 1-30

Wolkoff AN (1876) Die Lichtabsorption in den Chlorophyllösungen. Heidelberg University, Heidelberg 